
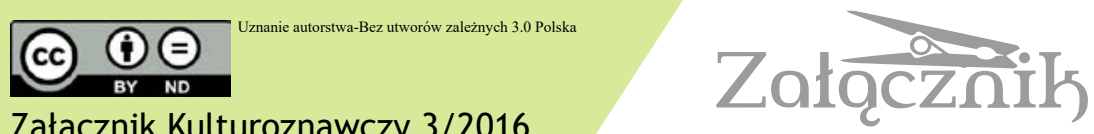

Załącznik Kulturoznawczy 3/2016

TEMAT NUMERU: KICZ NASZ WSPÓLCZESNY

\title{
O „DUCHOWOŚCI NASTĘPCZEJ” \\ I KICZOSFERACH EMOCJONALNYCH \\ W DWÓCH UJĘCIACH LITERACKICH \\ (IRZYKOWSKI - DEHNEL)
}

BRYGIDA PAWŁOWSKA-JĄDRZYK

Wydział Nauk Humanistycznych Uniwersytetu Kardynała Stefana Wyszyńskiego w Warszawie

Faculty of Humanities Cardinal Stefan Wyszyński University in Warsaw (Poland)

brygida.pawlowska@gmail.com

\section{WPROWADZENIE}

Docelowym tematem niniejszego szkicu uczyniłam zjawiska związane z pewną - współcześnie, jak sądzę, coraz powszechniejszą - postawą życiową (w szerokim znaczeniu tego pojęcia, obejmującym także sferę motywacji, uczuć i emocji człowieka), którą najprościej można by scharakteryzować jako mariaż nieautentyczności z imitacjonizmem. Tak określoną problematykę chciałabym rozpatrzyć, skupiając się na uczuciach miłosnych (jako szczególnie „dotkliwych”, a przy tym bodaj najbardziej zmitologizowanych), a raczej na pewnym ich zobrazowaniu literackim, które zdaje się przynosić trafną diagnozę uczuciowości typowej dla społeczeństwa konsumpcyjnego, ogarniętego obsesją pieniądza, poddanego dyktatowi mass mediów oraz ulegającego za ich sprawą presji popkulturowych ideałów i wyobrażeń. Taką diagnozę odnajduję w mikropowieści Jacka Dehnela Miłość korepetytora, składającej się - wraz trzema innymi utworami - na nominowany do Nagrody Literackiej Nike tom o znaczącym tytule Balzakiana (2008). Bez wielkiej przesady można rzec, iż zbiór ten przynosi egzemplifikacje istotnych aspektów koncepcji Abrahama Molesa - badacza, który akcentował uniwersalność kiczu (to jest wskazywał na fenomen jego obecności we wszystkich dziedzinach życia, zarówno jednostkowego, jak i zbiorowego), uznając przy tym za jego domenę w szczególności sferę życia codziennego. Według tego autora kicz - mający w swej istocie podłoże psychologiczne 
i nader wyraziście przejawiający się w stosunku człowieka do świata przedmiotów - jest estetyką mieszczańskiego dobrobytu, to rys każdej kultury opartej na posiadaniu ${ }^{1}$.

Jacek Dehnel, podejmując artystyczną próbę określenia kondycji społeczeństwa polskiego po transformacji politycznej 1989 roku, świadomie odwołuje się do odległej tradycji prozy realistycznej, ufundowanej przez monumentalną Komedię ludzka Honoriusza Balzaka, aczkolwiek stosowane przez niego metody twórcze tradycję tę wyraźnie przekraczają ${ }^{2}$. W płaszczyźnie ideowej jego utworu aspekty balzakowskie uwidaczniają się bodaj najwyraźniej poprzez demaskatorski krytycyzm, który prowadzi do obnażenia kruchości moralnej społeczeństwa uwikłanego w świat wypełniony rzeczami, opanowanego żądzą posiadania i sukcesu ${ }^{3}$ (wyznaczniki owego sukcesu są tu już oczywiście uwspółcześnione). Jeśli zaś chodzi o rozpoznania Dehnela, które są związane z zagadnieniem „wtórności” uczuć i emocji jednostkowych, jak i pewne specyficzne cechy ukształtowania narracyjnego, w kontekście tej prozy można wskazać na mniej oczywistą tradycję: wydaje się, że stanowi ją jedyna powieść Karola Irzykowskiego - Pałuba (1903).

Zarówno diagnozy związane z problemem „duchowości następczej”, jak i konteksty kulturowe, do których one odsyłają, są w obu przypadkach odmienne, co jednak nie wyklucza głębinowego pokrewieństwa opisywanych zjawisk. Obszarów światopoglądowo-artystycznej wspólnoty wymienionych pisarzy upatrywałabym w konsekwentnym kwestionowaniu mitu „dziewiczości” (spontaniczności) ludzkich uczuć i emocji oraz w „szyderczym” obnażaniu ich zapośredniczenia (służą temu między innymi komentarze

1 Zob. A. Moles, Kicz, czyli sztuka szczęścia. Studium o psychologii kiczu, tłum. A. Szczepańska i E. Wende, Warszawa 1978.

2 O zawieszeniu zbioru Balzakiana pomiędzy tradycją prozy realistycznej a twórczością postmodernistyczną zob. M. Kwaśnik, Między wiedzą a widzeniem. O sposobach przedstawiania świata w „Balzakianach” Jacka Dehnela, „Załącznik Kulturoznawczy" 2014, nr 1, s. 410-429.

3 „Balzac był pierwszym powieściopisarzem, który odkrył etykę pieniądza obowiązującą w ówczesnym społeczeństwie; pościg za finansowym sukcesem zastępował w nim religię i kodeks moralny, stając się podporą nowego systemu społecznego". D. Burt, 100 najwybitniejszych pisarzy wszech czasów, tłum. J.S. Sito, A. Dobrzańska-Gadowska, Warszawa 2001, s. 144. 
narratorów, ironia, parodia, satyryczne czy groteskowe przerysowania). W obydwu przypadkach w tórność - czy to wobec reprezentacji wzniosłych idei (Irzykowski), czy wobec banalnych popkulturowych klisz i schematów (Dehnel) - powiązana jest z ekspansją kiczu na płaszczyźnie egzystencjalnej i obyczajowej, jako że idzie ona w parze z nieautentycznością postaw bohaterów oraz przekształcaniem przez nich uczuć w fetysze.

\section{OD ROMANTYCZNYCH IDEAŁÓW PO "GARDEROBĘ DUSZY” I „NASTĘPCZY ŚWIAT ZJAWISK” (PAEUBA KAROLA IRZYKOWSKIEGO)}

Już pierwsi interpretatorzy nie odmawiali powieści młodopolskiego krytyka odkrywczości w badaniu mechanizmów motywacyjnych, a następne dziesięciolecia ugruntowały jej pozycję jako intrygującego traktatu psychologicznego ${ }^{4}$. Głównie w tej dziedzinie upatrywano doniosłości utworu, wskazując na jego prekursorstwo wobec psychoanalizy Freuda. Zapoczątkowana przez Stanisława Brzozowskiego ${ }^{5}$ tradycja interpretowania Pałuby w duchu krytyki kultury powraca w snutych przez badaczy analogiach między utworem Irzykowskiego a zainteresowaniami dwudziestowiecznej socjologii i antropologii kulturowej ${ }^{6}$.

Ograniczę się tu do przypomnienia, że Pałuba stanowi rozrachunek z zafałszowaniem myślowym i uczuciowym człowieka, którego świat wewnętrzny wypacza się pod wpływem różnych mitologii. Irzykowski mierzy przede wszystkim w spuściznę duchową romantyzmu, z całą jej ideologiczną bezkompromisowością i totalnością. Pałuba sprzeciwia się naiwnemu schematyzowaniu rzeczywistości, a także utrwalonym, zwłaszcza przez

4 Zob. m.in. J. Topass, Un précurseur de Freud et de Proust. Charles Irzykowski, „Pologne Littéraire” 1927, nr 40. Kilkanaście lat temu podsumowania dziejów recepcji powieści Irzykowskiego dokonał H. Markiewicz: „Pałuba” - bezimienne dzieło, [w:] idem: Przygody dzieł literackich, Gdańsk 2004, s. 177-218.

5 S. Brzozowski, Karol Irzykowski, [w:] idem, Współczesna powieść polska, Stanisławów 1906 (przedruk: Współczesna powieść i krytyka literacka, Warszawa 1971, s. 134-139).

6 Zob. A. Werner, Człowiek, literatura, konwencje, [w:] Z problemów literatury polskiej XX wieku, t. I: Młoda Polska, red. J. Kwiatkowski i Z. Żabicki, Warszawa 1965. 
literaturę, sposobom tłumaczenia tajników uczuciowości. Młodopolski pisarz demaskuje u podstaw ludzkich zachowań zepchnięte do podświadomości działanie pierwiastka intelektualnego (lekceważonego przez romantyzm i modernizm), który strzeże przed uszczerbkiem nasze przyjemności psychologiczne, czyli - by przywołać oryginalne sformułowania - „represjonuje” myśli z dziedzin kompromitujących - tak zwane "punkty wstydliwe”, które przed dotarciem do świadomości muszą zostać w "garderobie duszy” obleczone w przyzwoity „płaszczyk”. Powieść przynosi wiele przykładów instynktownego wręcz wyrachowania na obszarze rzekomo zarezerwowanym dla porywów serca. Dotyczy to zwłaszcza różnorodnych działań protagonisty, Piotra Strumieńskiego, oraz jego kolejnych żon - Angeliki i Oli. Bohaterowie ci mniej lub bardziej świadomie dążą do czerpania satysfakcji z różnych, często tragicznych ról narzucanych im przez otoczenie lub podejmowanych $\mathrm{z}$ własnej inicjatywy pod wpływem fascynacji pewnymi ideami. Irzykowski dowodzi, że wszelkie uczucia (w tym miłość, smutek, rozpacz) „w czystej formie” właściwie nie występują; mogą zaistnieć jedynie jako namiastki wielkich namiętności opiewanych przez poetów, jako formy zdegenerowane i wyblakłe w stosunku do swoich pierwowzorów, ponieważ - jak czytamy w Pałubie - „ponad inne popędy ludzkie, głód, miłość i instynkt samozachowawczy, górą idzie egoizm intelektualny, ten zwłaszcza, który objawia się w chęci przeprowadzenia komedii swego charakteru" " Zarówno fabuła Pałuby, jak i liczne zawarte w niej fragmenty autotematyczne dowodzą, że w realnym życiu, paradoksalnie, to właśnie wzniosły ideał spełnia często rolę „listka figowego” dla niskich popędów, występków i zwykłych ludzkich nieprawości.

Szczególnie uczucia miłosne jawią się w Pałubie jako rodzaj gry podporządkowującej spontaniczność konwencjom (także językowym) - gry tworzącej wtórną rzeczywistość, w której chwilowo przestają obowiązywać reguły realnego życia. Niemal wszystkie postacie w powieści urzeczone są słowem „miłość”, stanowiącym niejako mini-fabułę erotycznych perypetii. Wieloletni związek Oli i Piotra Strumieńskich napiętnowany

${ }^{7}$ Kwestie te znajdują rozwinięcie w rozdziale IX Pałuby, zatytułowanym O punktach wstydliwych i o garderobie duszy (kontrabandzie).

8 K. Irzykowski, Pałuba, [w:] idem, Pałuba. Sny Marii Dunin, oprac. Aleksandra Budrecka, Wrocław 1981, s. 281. 
jest znakiem flirtu i eksperymentu, co uwydatnia walor antyromantyczny (brak spontaniczności) i antynaturalistyczny (wyrachowanie ponad „ślepy instynkt") ich postępowania, w którym słowa brzmią jak aktorska kwestia, a czynom towarzyszy wystudiowana teatralna poza. Pozory oraz naiwne i z gruntu kiczowate samostylizacje łatwo ośmieszyć poprzez nasycenie narracji ironią, denuncjowanie przez narratora faktów wstydliwie skrywanych przez postacie, przytaczanie wypowiadanych przez nie frazesów (po z górą stu latach podobną strategię kompromitacji własnych bohaterów zastosuje i Jacek Dehnel). Na przykład w niektórych partiach Pałuby, które charakteryzują postawę drugiej pani Strumieńskiej, Oli, narracja miejscami rezygnuje $\mathrm{z}$ formy mowy zależnej na rzecz mowy niezależnej. W ten sposób manifestuje się wyjątkowa czujność narratora (autora wpisanego) wobec słowa i jego fałszywych znaczeń stanowiących budulec „wieżyczek nonsensu”. W powieści Irzykowskiego - poza wtrąceniami - funkcję ironicznego czy wręcz szyderczego komentarza często przejmuje korygujący cudzysłów. Wymusza on wzmożoną czujność wobec słów, które w istocie „same się z siebie naśmiewają”, jak w przytoczonym fragmencie charakteryzującym naiwność rozumowania Oli:

Bo już się go [Strumieńskiego - przyp. B.P.J.] nie bała, sama mu wyznała: „Pierwej to się ciebie bałam, a teraz nic a nic” lub dalej: „Ola pozwoliła i Strumieńskiemu zajrzeć za kulisy (?) swego serca i mówiła o swojej skrusze z powodu samobójstwa Gasztolda tak, żeby Strumieński mógł sobie pomyśleć: »Więc dla niej się nawet zabijają (zaraz pluralis), nie umiałem cenić tego skarbu!«"”.

Historia związku Strumieńskiego i Angeliki jest już znacznie poważniejsza w skutkach, a emocje z nią związane mają charakter skrajnie destrukcyjny, przyświeca jej bowiem idea zrodzona $\mathrm{z}$ fascynacji romantyzmem - idea, która chce być religią, wymaga ofiary wielkiej i całościowej. Najjaskrawiej uwidacznia się to właśnie na przykładzie losu pierwszej żony Piotra. Kobieta ta, zapatrzona w ideał miłości platonicznej, niecierpliwie oczekuje porodu, z którym wiąże nadzieje na zajścia tragiczne (!), a gdy okazują się one płonne (poród przebiega bez powikłań), postanawia popełnić samobójstwo i rzuca

9 Ibidem, s. 184. 
się do studni. Angelika wyrzeka się życia „dla symetrii”, dla „zaokrąglenia” rzeczywistości, zbliżenia jej do idealistycznych pragnień.

Pałuba kładzie nacisk na wewnętrzne sprzeczności uczuć takich jak miłość i cierpienie, których jednoznaczność - jak stara się pokazać Irzykowski jest jedynie postulatem. Powieść ujawnia, że nawet ból i rozpacz nie są „czyste”, ukrywa się w nich bowiem dziwaczna przyjemność, przez samo swoje zaistnienie kolidująca z romantyczną ideą cierpienia aż do szaleństwa. Zwłaszcza miłość jawi się jako uczucie wewnętrznie złożone i sprzeczne, które łączy w sobie pierwiastki kontrastowe (na przykład wzniosłość ze śmiesznością, duchowość ze zmysłowością, altruizm z egoizmem), jednoczy dziedziny umiłowane i wzgardzone. Jednak bohater Pałuby, przyswoiwszy sobie katalog „słów-postulatów”, „słów-potworów”, z całym jego znaczeniowym ocenzurowaniem, nie akceptuje własnych uczuć i emocji, $z$ determinacją dążąc do realizacji frazesu. Sprawa jest skomplikowana, gdyż nieprecyzyjne, jednostronne słowa-pojęcia łączą się ze sobą w różne kombinacje, tworząc tym samym odrębny „na stępczy świat zjawisk”, w którym błędy pretendują do miana faktów („niektóre słowa zakorzeniają się w mózgu, utrwalają, otaczają pewną melodią, pewną sferą uczuć i kojarzeń podsłownych"10). Słowo-postulat rezerwuje dla siebie pewien obszar w mózgu, przy czym pobudza inne wyobrażenia tak skutecznie, że choćby uczucie to realnie nie istniało, panoszą się one w myślach jako zjawiska rzeczywiste. Mogą nawet wywierać szczere skutki (jak rozpacz, łzy, a nawet samobójstwo), gdyż człowiek - pogrążywszy się w następczym życiu duszy zatraca świadomość reprodukowania obcych wzorów. Irzykowski zauważa, że proces ten jest tak daleko posunięty, iż pewne słowa straciły już związek ze swoją genezą, „z narzędzi stały się panami” - teraz to do nich dosztukowuje się pojęcia i treści, a nie odwrotnie. Najistotniejszym rozpoznaniem Pałuby w tym zakresie, opisującym zjawiska językowe o poważnych konsekwencjach psychologicznych, jest tak zwana „teoria bezimienności”, która zostaje drobiazgowo wyłożona $\mathrm{w}$ autotematycznych partiach powieści ${ }^{11}$.

10 Ibidem, s. 354.

11 Więcej na ten temat pisałam w: B. Pawłowska-Jądrzyk, Przeciw aforystyczności. Świadomość językowa w „Pałubie” Karola Irzykowskiego, „Teksty Drugie” 2001, nr 6, s. 77-94 (także w: eadem, Sens i chaos w grotesce literackiej. Od "Pałuby” do „Kosmosu”, Kraków 2002, s. 117-141). 
Nowatorska i poniekąd ekscentryczna powieść Irzykowskiego pokazuje, że kultura - jako sfera nadbudowana nad rzeczywistością - stanowi narzędzie kreowania nieautentyczności, która zagraża podmiotowej tożsamości człowieka, bowiem atrakcyjność produkowanych przez nią wzorców osobowych, behawioralnych i emocjonalnych zaprzecza naturalnym ludzkim skłonnościom i tęsknotom, zastępując je schematami. Założenie to leży u podstaw zabiegów zmierzających do rewizji utrwalonych w świadomości społecznej teorii, wmówien i pozorów, które powieść usiłuje rozbijać czy poddawać przewartościowaniu. Irzykowski obnaża nadużycia na wymienionych polach między innymi poprzez demontaż idealizmu, odkrywanie niedoskonałości języka i dekonstruowanie różnych konwencji literackich. Pałuba jest przede wszystkim utworem o krachu romantycznych ideałów oraz rozrachunkiem estetycznym i filozoficznym z modernizmem. Atakuje także różne uproszczenia myślowe („symetryczności”), rozpropagowane w społeczeństwie zwłaszcza przez literaturę, oraz modne schematy przeżywania i odczuwania zgodne z upodobaniami własnej epoki (między innymi płytki dekadentyzm rodem z entuzjastycznie przyjętego przez modernistów Bez dogmatu Henryka Sienkiewicza). Trzeba jednak pamiętać, że rozrachunku tego pisarz dokonuje z perspektywy początku XX wieku. Mimo wieloaspektowego prekursorstwa ${ }^{12}$ Pałuby, jej związek z Młodą Polską pozostaje bardzo silny; charakter tego związku bywa słusznie określany jako „zależność przez negację"13.

Nieautentyczność zachowań związanych z życiem uczuciowym człowieka na przełomie XIX i XX stulecia nie stanowiła tematu zupełnie nowego, ten sam problem pojawił się w literaturze już wcześniej i w jednej ze swoich

12 Interpretatorzy od dawna podkreślali nowatorstwo powieści Irzykowskiego i mnożyli płaszczyzny zależności Pałuby z najróżniejszymi nurtami (dekadentyzmem, empiriokrytycyzmem, konwencjonalizmem, formizmem, autentyzmem, surrealizmem, egzystencjalizmem) i nazwiskami (Schopenhauer, Gide, Freud, Adler, Mach, Sartre, Heidegger, Nietzsche, Proust, Gombrowicz). Notabene, o pewnym przeoczonym aspekcie prekursorstwa powieści Irzykowskiego wobec nurtu parodystyczno-groteskowego w Polsce pisałam w artykule Parodia i groteska w „Pałubie” Karola Irzykowskiego, „Przegląd Humanistyczny” 1995, nr 5, s. 153-168.

13 A. Werner, op. cit., s. 356. 
odmian zaistniał jako, zrodzony na gruncie naturalizmu, bowaryzm ${ }^{14}$. Pałubę wyróżnia raczej odmienne ujęcie zagadnienia nieautentyczności, a także powiązanie go z krytyką języka, wszak - jak pokazuje Irzykowski mówić znaczy powoływać wtórną rzeczywistość, zakorzenioną w utwierdzonych przez język idées fixes. W tej perspektywie osobowość nie jest już integralnym i nienaruszalnym zespołem dyspozycji pierwotnych, cech wrodzonych, okazuje się bowiem, że w życiu wewnętrznym mają swój udział zmienne formy kulturowe fałszujące nie tylko zachowania, ale i procesy psychiczne. Rozpoznaniom Irzykowskiego zdaje się patronować Fryderyk Nietzsche:

Następcze usprawiedliwienie istnienia. Niejedna myśl [- a przypuszczalnie „każdej chwili mamy tylko taką myśl, dla której posiadamy na podorędziu słowa mogące ją w przybliżeniu wyrazić" - przyp. B.P.J.] przyszła na świat jako błąd i urojenie, ale stała się prawdą, gdyż ludzie podstawili później pod nią substrat rzeczywistości ${ }^{15}$.

Na zakończenie uwag o Pałubie warto raz jeszcze podkreślić fakt, że demaskatorski (wobec różnorodnych błędów i urojeń) charakter powieści przejawia się nie tylko w motywach i obrazach, ale bardzo często wynika z poczynań wpisanego w tekst autora - wyodrębnionej siły intelektualnej, zewnętrznej wobec przedstawionych wydarzeń, lecz nadającej im zależny od swojego upodobania koloryt. Groteskowość wcale nie wydaje się tu konieczną funkcją rzeczywistości przedstawionej, a efekt dysonansowy nadaje jej raczej specyficzne ukształtowanie samej wypowiedzi o świecie. Przenoszenie akcentów parodystyczno-groteskowych z obrazów na sposoby oraz środki przedstawiania jest dla powieści Irzykowskiego bardzo charakterystyczne i stanowi wykładnik ironicznego stosunku autora do bohaterów, uwypukla jego nieprzerwaną obecność, manifestuje krytycyzm

${ }^{14} \mathrm{O}$ młodopolskich pisarzach zajmujących się tym problemem pisze A. Budrecka w Słowie wstępnym do „Pałuby” zawartym w: K. Irzykowski, op. cit., s. LVIII.

15 [Cyt. za:] F. Nietzsche, Aforyzmy, oprac. i wstęp S. Lichański, Warszawa 1973, s. 36-37 (źródło całości: Wędrowiec i jego cień, tłum. K. Drzewiecki; źródło cytatu wtrąconego: Jutrzenka, tłum. S. Wyrzykowski). 
i subiektywizm sądów. Podobnie „naznaczony szyderstwem” ton cechuje narrację Balzakianów ${ }^{16}$.

\section{3. „UCZUCIE JAKO CYTAT” - \\ O EMOCJACH W DOBIE POPKULTURY (MIŁOŚĆ KOREPETYTORA JACKA DEHNELA)}

Pomimo odmiennego kontekstu macierzystego, który wiąże się z ponadstuletnim dystansem, jaki dzieli publikację Pałuby Irzykowskiego od Miłości korepetytora Dehnela, można zarysować pomiędzy tymi utworami kilka płaszczyzn porównania. Poza drobnymi elementami stanowiącymi być może aluzję literacką (bohaterka z Balzakianów ma na imię Angelika - tak samo jak pierwsza żona Piotra Strumieńskiego) oraz pewnymi, wzmiankowanymi

16 Zob. np. trzy fragmenty reprezentujące strategie postaciowania stosowane w Miłości korepetytora:

„[Adrian Helsztyński] Miał na sobie długi, ciemnoszary płaszcz z aksamitnymi wyłogami (wyglądał trochę na Bossa; lumpeks na Chłodnej, 26 złotych), popielaty japoński szal z surowego jedwabiu (wyglądał trochę na Kenzo; lumpeks na Brackiej, 8 złotych), pod tym grafitowy garnitur Zegna (sprzedawany na Allegro w pierwszy dzień Bożego Narodzenia, przez co poszedł za grosze, bo właściciel nie wyznaczył ceny minimalnej, a wszyscy licytujący trawili świąteczne śniadanie) i srebrzysty krawat spięty szpilką z perłą (wygrzebaną ze stosu różnych śmieci u Cyganów na Kole). Wyglądał jak wcielony luksus w stylu vintage”. J. Dehnel, Miłość korepetytora, [w:] idem, Balzakiana, Warszawa 2010, s. 258.

„Sandra Kwiczoł, prócz rozmaitych słabości ducha (hazard, seks w wielkim mieście i substancje halucynogenne) miała i pewną słabość ciała: była mianowicie malutka, maciupcia. I, co za tym często idzie, uwielbiała wysokich mężczyzn. Można sobie wyobrazić, co poczuła ta gniewna osóbka, kiedy dwadzieścia kroków przed sobą ujrzała dwumetrowego olbrzyma w rozmaitych odcieniach szarości i srebra; stała jak urzeczona i wszystko w niej wzdychało i drżało, nawet maleńki błyszczyk w maleńkiej torebce [...]”. Ibidem, s. 280.

„Serce Angeliki Włost, miękkie jak pralinka z białej czekolady wystawiona na lipcowy skwar, otwierało Adrianowi drogę do wszystkiego, czego przez lata pragnął; było jak kamień filozoficzny (choć nie było to serce z kamienia, co to, to nie!), który mógłby mu przynieść dowolną sumę pieniędzy, bo jako ukochany i jedyny zięć mógłby liczyć nie tylko na królewnę za żonę, ale i z pewnością na pół królestwa”. Ibidem, s. 321. 
wcześniej, literackimi sposobami kompromitacji nieautentyczności bohaterów, na plan pierwszy wysuwa się krąg zagadnień związanych z problemem „duchowości następczej”. W przypadku Miłości korepetytora określenie to oznacza mniej lub bardziej bezwolne powielanie przez postacie pewnych schematów zachowań, myślenia i przeżywania propagowanych przez dzisiejszą popkulturę. Skrótowo rzecz ujmując, Dehnel kreśli grubą kreską satyryczny obraz społeczeństwa polskiego po transformacji ustrojowej, bezlitośnie obnaża uwikłanie swoich bohaterów w resentymenty oraz dążenia i ideały typowe dla ery konsumpcji, które określają pewne wzorce postaw czy zachowań, ale i - jak można sądzić - generują „kiczosfery współczesnej emocjonalności"17.

Bodaj najważniejszym tematem Miłości korepetytora, zarysowującym się zrazu poprzez na pozór niewinne działania i snobistyczne pozy postaci, jest nieautentyczność, udawanie kogoś lepszego, niż się jest w istocie (przy czym - inaczej niż w Pałubie - chodzi tu przede wszystkim o stworzenie atrakcyjnej fasady z myślą o innych). W karykaturalny sposób kwestia ta zostaje zobrazowana już w pierwszej scenie utworu: jego główny bohater, Adrian Helsztyński, odesławszy nieefektownie wyglądającą taksówkę, wsiada do bardziej reprezentacyjnej, by po kłótni z dyspozytorką podjechać raptem kilkanaście metrów dalej - pod drzwi znajdującego się po drugiej stronie ulicy hotelu, w którym ma umówione spotkanie z potencjalnym klientem. „Profesja”, jaką para się Adrian, jest zresztą szczególnego rodzaju ów „korepetytor od dobrych manier” określa istotę swojej działalności w rozmowie $\mathrm{z}$ Włosem - nowobogackim prezesem firmy drobiowej i ojcem apatycznej dwudziestolatki imieniem Angelika - jako „wychowywanie ludzi do szczęścia” (przy innej okazji Helsztyński przedstawia siebie jako „rzeźbiarza klasy i dobrego samopoczucia”, człowieka, który uczy „sztuki kamuflażu: jak wyglądać na kogoś znacznie bogatszego, zdolniejszego, ciekawszego i lepiej wychowanego, niż jest się w rzeczywistości”18). Taka oferta trafia na podatny grunt, gdyż prezesostwo już dawno postanowili, by ze swojej jedynaczki „zrobić czempionkę towarzyską, która będzie się pojawiała jako celebrytka we wszystkich numerach »Vivy! $\mathrm{i}$ »Gali« u boku

${ }^{17}$ Nawiązuję tu do tytułu książki Kiczosfery współczesności, red. W.J. Burszta, E.A. Sekuła, Warszawa 2008.

18 J. Dehnel, op. cit., s. 295-296. 
najlepszych męskich partii, zrobiona przez najlepszych stylistów i ubrana przez najlepszych dizajnerów"19.

Młody Adrian Helsztyński - obdarzony urokiem osobistym potomek zubożałego, ale „pańskiego” rodu, mimo zaopatrywania się w lumpeksach „wyglądający jak chodząca elegancja” i roztaczający wokół siebie „atmosferę grandeur" - znakomicie odnajduje się w środowisku, które wartość człowieka upatruje w zaradności i atrybutach zewnętrznych. Co prawda trafia mu się wyjątkowo oporny materiał, gdyż córka Włosa nie ma absolutnie żadnych pasji ani zainteresowań, ale przychodzi mu z pomocą przypadek: wpada w oko Sandrze Kwiczoł, rywalce Angeliki z grupy na SGH i spadkobierczyni innej fortuny, co „w tym konflikcie o władzę i powodzenie” z miejsca czyni go w oczach prezesówny kimś pożądanym. Fragment utworu opisujący relacje między obydwiema dziewczynami cechuje nie tylko ton satyryczny, ale wręcz mizoginiczna zjadliwość:

[...] dziedziczka fortuny drobiowej ścierała się tu z dziedziczką sieci warsztatów Audi, każda z nich otoczona wianuszkiem dwórek i bezpiecznym kordonem banknotów o wysokich nominałach. Robiły sobie nawzajem wszystko, co zdolne są zrobić młode kobietki zapiekłe w swoim gniewie: oszczerstwa, obrzydliwe plotki, pretensje i ukryte między komplementami wyzwiska latały między nimi jak pociski pod Verdun, wszystko to jednak było po wierzchu lukrowane, tak, że średnio wnikliwy obserwator nie zorientowałby się, że jedna drugą najchętniej utopiłaby w szklance wody ${ }^{20}$.

Kolejne etapy rozwoju zdarzeń pokazują, jak z upływem czasu - w miarę postępów Angeliki w zakresie autokreacji - to, co wynikło z chęci upokorzenia Sandry Kwiczoł, staje się początkiem zmiany stosunku prezesówny do świata i zarzewiem jej gwałtownej namiętności do przystojnego korepetytora. Angelika Włos $(\mathrm{t})^{21}$, obojętnie pławiąc się w nowobogackim dobrobycie $^{22}$ i czyniąc przy pomocy Helsztyńskiego stopniowe postępy na

19 Ibidem, s. 257.

20 Ibidem, s. 279-280.

${ }^{21}$ Andżelika za radą Adriana dodaje do swojego nazwiska „t” i zaczyna podpisywać się „Angelika”, co idzie w parze z wymyśleniem rodzinnej legendy.

${ }^{22}$ Pisarz metodycznie i z dużą dozą ironii podkreśla uwięzienie swoich bohaterów w świecie przedmiotów, ich zniewolenie rządzą posiadania i predylekcję 
drodze do środowiskowego sukcesu, długo nie uświadamia sobie faktu istnienia uczuciowej konkurencji. Tymczasem Adrian miota się między kilkoma kobietami, czerpiąc z tych znajomości różne profity. Potajemnie utrzymuje satysfakcjonujący związek erotyczny z Darią Pieleszek, banalną dziewczyną zapoznaną w autokarze, musi też nieustannie wymawiać się od awansów Lidii Dereczko - podstarzałej konserwatorki wnętrz, której wiele zawdzięcza i u której nieodpłatnie pomieszkuje, co z czasem prowadzi do coraz bardziej dwuznacznych sytuacji. Helsztyński wykazuje nieprzeciętne zdolności przystosowawcze - nie tylko wypracowuje sobie atrakcyjny image chłopca $\mathrm{z}$ dobrego domu, ale i lawiruje między korzystnymi układami, płynnie nakłada kolejne maski, akceptując mniej czy bardziej nieszkodliwe ustępstwa moralne. (Relacja z Lidią Dereczko zostaje na przykład podsumowana w następujący sposób: „Dla Adriana stało się jasne, że jeśli nawet nie musi się prostytuować, to wchodząc do tego uroczego mieszkania, pełnego starych mebli i pięknych przedmiotów, wchodzi zarazem w pewien układ, którego istotną częścią jest okazywanie czułości i pewien rodzaj melancholijnych zalotów"23). W rezultacie Helsztyński zdaje się tracić orientację we własnych uczuciach i w finale utworu staje przed zupełnie nieoczekiwanym dylematem, którego rozstrzygnięcie przesądza o jego dalszym losie.

Można rzec, iż Jacek Dehnel w Miłości korepetytora kreśli karykaturalny obraz stylu zachowań, myślenia i przeżywania, który dominuje w społeczeństwie konsumpcyjnym (być może w szczególności - postkomunistycznym). Styl ten znamionuje „utrata duszy” (James Hillman), intelektualna i emocjonalna amnezja, pustka wywołująca potrzebę doraźnej ekscytacji, która prowadzi do groteskowych imitacji olśnień czy uniesień, zastępujących prawdziwe uczucia. Kunderowską prawdę o tym, że w dobie mass

do celebrowania kiczu. Dotyczy to zarówno rodziny Włosów, posiadaczy pretensjonalnej willi w Konstancinie wyposażonej między innymi w „empirowe fotele ze złotymi łabędziami” i „ekspres do kawy wart tyle, co samochód” (pokój Angeliki określony zostaje jako „rozdęty do przesadnych rozmiarów ambicjami rodziców i zatrudnionej przez nich projektantki wnętrz"), jak i samego Adriana Helsztyńskiego, który łamie sobie głowę nad sposobem nadania małemu mieszkaniu w bloku charakteru pałacowego. Zob. w tym kontekście: A. Moles, op. cit..

${ }^{23}$ J. Dehnel, op. cit., s. 273. 
mediów „naszą codzienną estetyką i moralnością stał się kicz” ${ }^{24}$, jak i z ducha postmodernistyczną świadomość „grzęźnięcia” w kliszach - utrwalonych w świadomości zbiorowej obrazach, różnorodnych schematach i stereotypach - najdobitniej wyraża scena, w której Angelika wyznaje Adrianowi miłość podczas spaceru przez - zmodernizowaną na wzór zachodni - nadwiślańską promenadę:

Stali obok siebie i patrzyli na różowe renifery czy może jelonki; dookoła nikogo, tylko nocna Praga, rozświetlone odciągi mostu Świętokrzyskiego i rozlegle tereny za ich plecami, gdzie kiedyś była elektrownia, a teraz jakiś deweloper przerabiał postindustrialne wnętrza na lofty i budował apartamentowce.

Wsiedli na jelonki. Najpierw on (uważnie, bo bał się, czy plastik nie pęknie pod ciężarem dwumetrowego faceta), potem ona. Trochę się śmiali, trochę udawali, że galopują, trochę patrzyli w gwiazdy, wzorem swoich rogatych rumaków. I siedzieli. I milczeli. I siedzieli, gadając. I siedzieli, milcząc. I byliby już zsiedli i zawrócili, gdyby nie jakiś cud emocjonalny, jakiś przewrót, przełom duchowy, który dokonał się w Angelice Włost pod wpływem oglądania sztuki współczesnej w postaci trzech reniferów z barwionego plastiku. Oto Angelika Włost, która żywiła głęboką niechęć do zajmowania jakiegokolwiek stanowiska, zdradzania się z jakimkolwiek pragnieniem czy chęcią, [...] poczuła, że po raz pierwszy od bardzo, bardzo dawna naprawdę czegoś pragnie. A jeśli pragnie, to pragnie do głębi, bez ograniczeń, dramatycznie, z rzucaniem się na szyję, całowaniem się na deszczu, wyprawami do romantycznych stolic europejskich, nocami i porankami w luksusowych hotelikach Wenecji i Paryża. [...]

[...] To, co nastąpiło potem, cały potok słów, przysiąg, błagań, pocałunków, płytkich i głębokich, wilgotnych i suchych, całe to tarzanie się,

24 „Wobec nieopanowanej potrzeby podobania się i zyskiwania tym samym coraz szerszej uwagi, estetyka mass mediów staje się nieuchronnie estetyką kiczu; w miarę jak środki przekazu ogarniają i przenikają całe nasze życie, kicz okazuje się naszą codzienną estetyką i moralnością. Do niedawna modernizm oznaczał nonkonformistyczny bunt przeciwko komunałom i kiczowi. Dzisiaj nowoczesność kojarzy się z żywiołową obecnością środków przekazu, a być nowoczesnym to czynić gwałtowne wysiłki, aby utrzymać się »w kursie«, to dostosowywać się do mody, być jeszcze bardziej dostosowanym niż inni. Nowoczesność przybrała szatę kiczu”. M. Kundera, Sztuka powieści. Esej, tłum. M. Bieńczyk, Warszawa 1998, s. 142. 
ocieranie o siebie jest właściwie nie do opisania w swojej bezładności, naiwności. Czy Angelika zachowała się desperacko? Nawet nie, zachowała się jak każdy, w kogo miłość uderzyła nagle, jak żagiel na wzburzonym jeziorze; nie wiedziała nawet, ba, oboje nie wiedzieli, że były to sa me cy tat y: cytat $z$ wijących się węży, z tulących się do siebie lampartów, cytaty z niezliczonych filmów o miłości, sekwencji pocałunków - twarze Gable’a i Leigh, Pitta i Jolie, Cruise’a i Kidman - słowa wypowiedziane przez wielkich poetów dobitniej i piękniej, a teraz nieudolnie powtarzane w ciemnościach zalegających brzeg rzeki, aż po cytat najbardziej banalny: „A ty, czy ty mnie kochasz?"25

Scena paroksyzmu afektów panny Włost w stosunku do Horsztyńskiego, zlokalizowana na tle kiczowatej scenerii z trzema amarantowymi reniferami z podświetlanego plastiku, prowadzi do brzemiennego w skutki rozpoznania. Jeśli chodzi o relacje między bohaterami utworu, rozpoznanie to dotyczy przede wszystkim zdania sobie sprawy z własnych uczuć przez Adriana (młody mężczyzna uświadamia sobie, że kocha „głupiutką”, niewyrobioną towarzysko Darię, i nie zrezygnuje z tego związku za żadną cenę $)^{26}$ oraz wyjścia na jaw zaskakującej prawdy o Angelice. Prezesówna okazuje się jednak wyjątkowo pojętną uczennicą, która stanowczo i bez większych

25 J. Dehnel, op. cit., s. 318-320; podkreślenia - B.P.J. O miłosnych cytatach w epoce „literatury wyczerpania” tak pisał Umberto Eco: „O postawie postmodernistycznej myślę jak o postawie człowieka, który kocha jakąś nader wykształconą kobietę i wie, że nie może powiedzieć jej »kocham cię rozpaczliwie«, ponieważ wie (i ona wie, że on wie), że te słowa napisała już Liala. Jest jednak rozwiązanie. Może powiedzieć: »Jak powiedziałaby Liala, kocham cię rozpaczliwie«. W tym miejscu, uniknąwszy fałszywej niewinności, oznajmiwszy jasno, że nie można już mówić w sposób niewinny, powiedziałby jednak ukochanej to, co chciał jej powiedzieć: że ją kocha, ale kocha ją w epoce utraconej niewinności”. U. Eco, Notatki na marginesie „Imienia róży”, [w:] idem, Imię róży, tłum. A. Szymanowski, Warszawa 2007, s. 738-739.

26 I w tym sensie jest to rzeczywiście opowiadanie o prawdziwym uczuciu, potwierdzające banalną prawdę, że „miłość jest ślepa”. Czego innego (innego uczucia, innej pary zakochanych) można by się jednak spodziewać z uwagi na tytuł utworu. Notabene, znamienne, że pisarz, który metodycznie obnaża kicz, wybiera zakończenie ni mniej, ni więcej-melodramatyczne. 
sentymentów potrafi „przypomnieć mistrzowi reguły gry” ${ }^{27}$ : wschodząca gwiazda kronik towarzyskich ważniejszych polskich tabloidów, zraniona dogłębnie w swej dumie, doprowadza do śmierci byłego korepetytora, kończąc przedtem znajomość za pośrednictwem stosownego, starannie wykaligrafowanego listu, który przesyła w eleganckiej, „odpowiednio dobranej” kopercie.

Dalsze losy Angeliki narrator kreśli krótko a sugestywnie:

Dwa lata później była już autentyczną hrabiną (kandydat nr 3, Juliusz hrabia Bończa-Kętrzyński, kancelaria Kętrzyński-Kociołek-Waligóra), co traktowała z przymrużeniem oka, porównując się często do Gilberty Swann. Uważano, że to urocze. Wybaczano jej drobne potknięcia, których z czasem było coraz mniej - zdarzało jej się niekiedy zapomnieć o czyichś urodzinach albo zbyt głośno szurnąć krzesłem. Na szczęście coraz gorsze wychowanie prawdziwych hrabin sprawiało, że podobne błędy były prawie niezauważalne. „Gala” miała wyłączność na fotoreportaż ze ślubu, wesele przeszło do legendy stołecznego restauratorstwa, bukiet panny młodej złapała najniższa druhna, Sandra Kwiczoł ${ }^{28}$.

Zarówno Pałuba, jak i Miłość korepetytora problematyzują kwestię „duchowości następczej”, prezentują sferę uczuć i emocji człowieka w aspekcie jej wtórności - jako pozbawioną spontaniczności, zapośredniczoną przez różnorodne konwencje i schematy kulturowe. Obaj pisarze - Irzykowski i Dehnel - wykorzystując między innymi przywileje narracji wszechwiedzącej, ironię oraz technikę karykaturalnego przerysowania, obnażają zafałszowania cechujące wypowiedzi, działania, myśli i emocje wykreowanych przez siebie bohaterów (notabene, miejscami też kwestionują autorytet samego narratora/autora wpisanego ${ }^{29}$. Jednak kulturowy kontekst tych praktyk

27 Zob. J. Dehnel, op. cit., s. 325.

28 Ibidem, s. 326.

29 W Pałubie narrator (autor wpisany) składa swego rodzaju samokrytykę $\mathrm{w}$ rozdziale XIX, zatytułowanym Trio autora. W Miłości korepetytora natomiast narracja miejscami upodabnia się do „popkulturowego bełkotu”, co ujawnia jej autoironiczność, parodystyczność, wewnętrzne zdialogizowanie (por. uwagi 
artystyczno-intelektualnych jest zgoła odmienny, inne też wiążą się z nimi diagnozy.

W Pałubie idealistyczne aspiracje postaci natrafiają na opór życia i szydercze wypaczenie, gdyż taka - czyli „beztematyczna” - jest natura Rzeczywistości, a człowiek z samej swej istoty skazany jest na odgrywanie „komedii” własnego charakteru. W konsumpcjonistycznym świecie Balzakianów nie ma już miejsca na wielkie ideały, dylematy moralne ani drobiazgowe introspekcje. O randze człowieka przesądzają: „fasada”, którą prezentuje on światu, umiejętność stwarzania pozorów, biegłość w manipulowaniu innymi. Kicz, którego istotą jest imitatorstwo i nieautentyczność, konformistyczne powielanie sprawdzonych schematów, duchowa egzaltacja, jawi się w tym kontekście zarówno jako źródło deprawacji, jak i jej skutek - zgodnie z koncepcją Hermana Brocha, kategoria ta przekracza zatem ramy estetyki, wkraczając w wymiar refleksji egzystencjalnej i etycznej ${ }^{30}$. Obszarem ekspansji kiczu w świecie przedstawionym Pałuby jest nade wszystko życie wewnętrzne jednostki i związane $\mathrm{z}$ nim imitacje idei, przeżyć czy postaw; w Balzakianach natomiast - sfera relacji międzyludzkich, naznaczona efekciarstwem, pozorem i walką o dominację, oraz, oczywiście, otoczenie materialne człowieka, a to w związku z tendencją do fetyszyzacji przedmiotów, która cechuje kulturę konsumpcyjną.

o „słowie dwugłosowym różnokierunkowym” w: M. Bachtin, Problemy poetyki Dostojewskiego, tłum. N. Modzelewska, Warszawa 1970, s. 275-309). Chyba najdobitniej to "nastawienie na cudze słowo" dochodzi do głosu w scenie nieudanego spotkania Adriana z Angeliką w kawiarni Faux-pas (po tym jak Helsztyński mówi dziewczynie, że najtrudniej wyglądać na kogoś ciekawego, jeżeli jest się kimś nieciekawym): „Zraniłeś ją, Shrek, zraniłeś ją na wskroś, uderzyłeś ją w podbrzusze, w słabiznę, w miękkie, w niezrośnięte ciemiączko. Och, Shrek, postawiłeś wszystko na jedną kartę; mogła w jednej chwili zatrzasnąć się jak muszla przegrzebka, jak szkatułka z laki, jak drzwiczki bentleya, jak skrytka w plecach sekretery, mogła porzucić wszelką chęć upokorzenia Sandry »Ziggy« Kwiczoł, dziedziczki salonów Audi [...], mogła to zlać, olać, a nawet pogrzebać w grobowcu swojego serca". J. Dehnel, op. cit., s. 296.

${ }^{30}$ Zob. H. Broch, Kilka uwag o kiczu i inne eseje, tłum. D. Borkowska, J. Garewicz, R. Turczyn, Warszawa 1998, s. 103-118. Autor ten za „złoty wiek” kiczu uznawał XIX stulecie, czyli epokę rozkwitu romantyzmu, ekspansji mieszczaństwa i rozwoju społeczeństwa przemysłowego. 
Irzykowski wierzy w Rzeczywistość (co widać chociażby w idei „pierwiastka pałubicznego"), a przekłamania na polu emocjonalnym, które denuncjuje, obnażając tandetne samostylizacje postaci, wywodzi ze ślepego idealizmu człowieka, który chce sprostać wzniosłym wzorom. Bohaterowie Dehnela ideałów już nie mają, skupiają się na stwarzaniu pozorów z myślą o innych - w celu prozaicznie pojętego powodzenia i materialnej korzyści. Nie obcują z prawdziwą sztuką, reprodukują bezmyślnie banalne popkulturowe schematy, zatracając się moralnie (choć bynajmniej nie zawsze do końca jak tytułowy korepetytor, który za ocknięcie się z konsumpcjonistycznego amoku płaci życiem). W tej bezmyślności i zgoła mechanicznej gotowości do przyjmowania kolejnych póz nie ma miejsca na „wewnętrzny heroizm”, znamionujący mimo wszystko bohaterów Pałuby. Można zatem rzec, iż Jacek Dehnel w Miłości korepetytora proponuje czytelnikowi przekształcony, szyderczo-ironiczny wariant starożytnego mitu o Pigmalionie i Galatei ${ }^{31}$. We współczesnym wydaniu nie jest to już jednak opowieść o wielkim uczuciu, ale o wielkiej deprawacji.

\section{Bibliografia}

Michał Bachtin, Problemy poetyki Dostojewskiego, tłum. N. Modzelewska, PIW, Warszawa 1970.

Hermann Broch, Kilka uwag o kiczu i inne eseje, tłum. D. Borkowska, J. Garewicz, R. Turczyn, Czytelnik, Warszawa 1998.

Stanisław Brzozowski, Karol Irzykowski, [w:] idem, Współczesna powieść polska,

Stanisławów - Warszawa 1906 (przedruk w: Współczesna powieść i krytyka literacka, PIW, Warszawa 1971).

Daniel Burt, 100 najwybitniejszych pisarzy wszech czasów, tłum. J.S. Sito, A. Dobrzańska-Gadowska, Świat Książki, Warszawa 2001.

Jacek Dehnel, Miłość korepetytora, [w:] idem, Balzakiana, W.A.B., Warszawa 2010. Umberto Eco, Notatki na marginesie „Imienia róży”, [w:] idem, Imię róży, tłum.

A. Szymanowski, Noir sur Blanc, Warszawa 2007.

Karol Irzykowski, Pałuba, [w:] idem, Pałuba. Sny Marii Dunin, oprac. A. Budrecka, Zakład Narodowy im. Ossolińskich, Wrocław 1981.

${ }^{31}$ Czyż Adrian Helsztyński sam siebie nie nazywa „rzeźbia rzem” (klasy i dobrego samopoczucia), a Angelika Włost nie stanowi jego, na swój sposób doskonałego, dzieła? 
Kiczosfery współczesności, red. W.J. Burszta, E.A. Sekuła, Wydawnictwo SWPS, Warszawa 2008.

Milan Kundera, Sztuka powieści. Esej, tłum. M. Bieńczyk, Czytelnik, Warszawa 1998.

Monika Kwaśnik, Między wiedza a widzeniem. O sposobach przedstawiania świata w „Balzakianach” Jacka Dehnela, „Załącznik Kulturoznawczy” 2014, nr 1.

Henryk Markiewicz, „Pałuba” - bezimienne dzieło, [w:] idem, Przygody dzieł literackich, Słowo/Obraz Terytoria, Gdańsk 2004.

Abraham Moles, Kicz, czyli sztuka szczęścia. Studium o psychologii kiczu, tłum.

A. Szczepańska i E. Wende, PIW, Warszawa 1978.

Friedrich Wilhelm Nietzsche, Aforyzmy, oprac. i wstęp S. Lichański, PIW, Warszawa 1973.

Brygida Pawłowska-Jądrzyk, Parodia i groteska w „Pałubie” Karola Irzykowskiego, „Przegląd Humanistyczny” 1995, nr 5.

Brygida Pawłowska-Jądrzyk, Przeciw aforystyczności. Świadomość językowa $w$ „Pałubie” Karola Irzykowskiego, „Teksty Drugie” 2001, nr 6 (także w: eadem, Sens i chaos w grotesce literackiej. Od „Pałuby” do „Kosmosu”, Universitas, Kraków 2002).

Jean Topass, Un précurseur de Freud et de Proust. Charles Irzykowski, „Pologne Littéraire" 1927, nr 4.

Andrzej Werner, Człowiek, literatura, konwencje, [w:] Z problemów literatury polskiej XX wieku, t. I: Młoda Polska, red. J. Kwiatkowski, Z. Żabicki, PIW, Warszawa 1965.

\section{On 'Subsequent Spirituality' and Emotional Kitsch Spheres in Literature (Irzykowski - Dehnel)}

This article examines a phenomenon associated with a certain - and today increasingly common - attitude in life that can most simply be described as the marriage of inauthenticity with imitationism. The author focuses her attention on feelings of love (as particularly 'severe', and at the same time probably the most mythologised), or rather on their literary depiction, which allows an accurate diagnosis to be made of the sensibility typical of a consumer society obsessed with money, subject to the dictates of mass media and under pressure from the ideals and ideas of pop culture. A diagnosis of this kind comes in the form of Jacek Dehnel's short story Miłość korepetytora 
[Love of the Tutor], which together with three other stories comprises the volume Balzakiana (2008). The young Polish writer, attempting to determine the condition of Polish society after the political transformation in 1989, makes conscious reference to the distant tradition of realistic prose from the legacy of Honoré de Balzac. As for a review of the sphere of individual feelings and emotions falsified by various stereotypes and abstract ideas, one can look to a tradition closer to Dehnel: namely the only novel of Karol Irzykowski - Pałuba [The Hag] (1903). The article shows some commonalities between the Young Poland concept of 'successive-world phenomena' and the contemporary vision of determining the emotional sphere through pop culture templates on the experience of romantic elation. References to the diagnoses of Abraham Moles, Milan Kundera and Hermann Broch allow, additionally in the cited contexts, the issues of 'exaltation as a replacement of spirituality' and kitsch as 'our daily aesthetic and morality' to be highlighted.

Keywords: sensibility in the era of pop culture, authenticity, exaltation, consumer culture, imaginative templates, existential kitsch 


\section{Wydawnictwo Naukowe UKSW poleca}

\section{Rzecz w kulturze}

(red.) Brygida Pawłowska-Jądrzyk, Dorota Dąbrowska

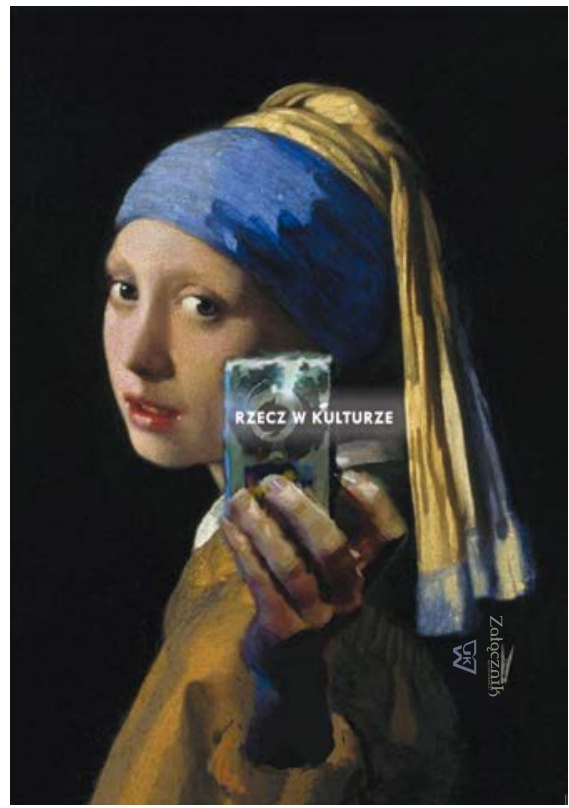

„Studia zebrane w tomie Rzecz w kulturze ukazują status i funkcjonowanie różnych przedmiotów w środowisku kulturowym człowieka, przy czym materiału do analiz dostarczyły dawne i współczesne teksty kultury, w tym zwłaszcza utwory literackie, filmy i reklamy. Książka reprezentuje nurt określany jako „posthumanistyczny” i jest kolejnym głosem w dyskusji o rzeczach, toczącej się ostatnio w wielu gremiach naukowych w Polsce i na świecie. Artykuły w niej zebrane analizują ciekawie, wnikliwie i przekonująco funkcje, zależności kontekstowe, charakter znakowy przedmiotów oraz sposoby ich przedstawiania w tworzywie językowym i przy użyciu technik filmowych. Ta bogata i wartościowa publikacja z pewnością będzie wykorzystywana w dydaktyce akademickiej, znajdzie też odbiorców wśród kulturoznawców, badaczy filmu i literatury".

Prof. dr hab. Teresa Dobrzyńska 